
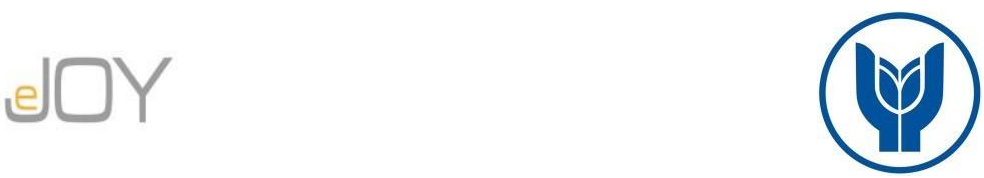

Erorhan Akkuş, İ., Çakıcı, A. C. / Journal of Yasar University, 2021, 16/63, 1398-1413

\title{
Yöneticiler Perspektifinden Otel Sadakat Programları Üzerine Bir Değerlendirme
}

\section{An Evaluation On Hotel Loyalty Programs From The Managers Perspective}

\author{
İlayda AKKUŞ ERORHAN, Mersin Üniversitesi, Türkiye, ilaydakkus@gmail.com \\ Orcid No: 0000-0002-1155-3538 \\ A. Celil ÇAKICI, Mersin Üniversitesi, Türkiye, celilcakici@ mersin.edu.tr \\ Orcid No: 0000-0002-9192-1969
}

\begin{abstract}
Öz: Otellerde uygulanan sadakat programları, müşteri devamlılı̆̆ının sağlanmasında kullanılan en önemli satış geliştirme araçlarından biridir. Bu doğrultuda araştırmanın amacı; uluslararası otel yöneticilerinin perspektifinden otel sadakat programlarının değerlendirilmesidir. Veriler, İstanbul ve Ankara'da faaliyet gösteren uluslararası zincir otellerin yöneticilerinden yarı yapılandırılmış görüşme yoluyla toplanmıştır. Görüşmeler 2020 yll Şubat ayında gerçekleştirilmiş olup; elde edilen veriler içerik analizine tabi tutulmuştur. Yöneticilerin sadakat programlarından temel beklentilerinin müşterilerini tanıma, müşteri devamlılı̆̆ să̆lama ve bu doğrultuda gelirleri arttırma olduğu tespit edilmiştir. Müşteri bağlllı̆̆ să̆lama konusunda en önemli hususun, otel işletmeleri tarafindan sadakat programı kapsamında verilen avantajlar olduğu belirlenmiştir. Sadakat programları uygulamasında personel ve tanitım giderlerinin en yüksek maliyet kalemi olduğu bulgulanmıştır. En sık yaşanan sorunların sistem kaynaklı sorunlar olduğu ve çoğu zaman işletme düzeyinde çözümler üretildiği ortaya çıkmıştır. Sadakat programı uygulamasının kilit başarı faktörünün, işletmenin kendisi olduğu tespit edilmiştir. Araştırma, otel yöneticilerine hem işletme hem de müşteri açısından maksimum faydayı sağlayacak dengeli bir sadakat programı gelişstirip uygulamaları önerisi ile son bulmaktadır.
\end{abstract}

Anahtar Kelimeler:Müşteri Sadakati, Sadakat Programları, Otel İşletmeleri

JEL Siniflandirmast: L83, L86, M31

Abstract: Loyalty programs applied in hotels are one of the most important sales promotion tools used to ensure customer retention. In this direction, the aim of the research is to get an evaluation on hotel loyalty programs from the perspective of international hotel managers. The data were collected through semi-structured interviews from the managers of international chain hotels operating in Istanbul and Ankara. The interviews were held in February 2020 and the obtained data were subjected to content analysis. It had been determined that the main expectations of managers from the loyalty programs were the knowing their customers, ensuring customer retention and increasing revenues accordingly. The most important issue in ensuring customer loyalty was found to be the advantages offered by hotel businesses within the scope of the loyalty program. In the implementation of loyalty programs, it was revealed that personnel and promotional expenses were the highest cost items. It had been determined that the most common problems were system-related problems and thus the solutions were usually developed at the business level. It had been found that the key success factor of loyalty program implementation was the business itself. The study concludes with the proposal that hotel managers should develop and implement a balanced loyalty program providing the maximum benefit for both the business and the customer.

Key Words: Customer Loyalty, Loyalty Programs, Hotel Businesses

JEL Classification: L83, L86, M31

\section{Giriş}

Aynı sektörde faaliyet gösteren, benzer özelliklere sahip ürünleri aynı pazarlara sunmaya çalışan işletmeler arasında büyük bir rekabet yaşanmaktadır. Teknolojinin hızla değişmesi ve gelişmesi, eğitim seviyesinin yükselmesi, müşterilerin tercih edebileceği ürün alternatiflerinin 
her geçen gün artması ve pazarlarda yaşanan hızlı değişimler, pazarlama yöneticilerinin yeni nesil bir müşteri ilişkileri yönetimi stratejisi geliştirmelerine zemin hazırlamıştır(Yıldırım, 2005: 2). Bu sayede müşteri istek ve beklentilerini karş1layarak devamlılık gösteren bir müşteri memnuniyetini ve sadakatini sağlamayı amaçlamışlardır(Ay, 2014: 2).

Sadakat programları, satın alma davranışının devamlılığını sağlamak amacı ile uygulanan teşvik programlarıdır(Demirel, 2007: 60). Bu programlar, müşterilerin markaya bağlılığını sağlarken aynı zamanda onlar hakkında bilgi edinip tercihlerine göre ürün sunmayı amaçlamaktadır. Bununla beraber, müşteriler ile ilişkiler süreklilik kazandığında ve işletmeye bağlılık arttığında çapraz satış uygulaması, işletmeler için büyük önem taşımaktadır.

Sadakat programları, turizm endüstrisinin çeşitli alanlarında sıklıkla uygulanmaktadır. Havayollarının yanı sıra, özellikle uluslararası zincir oteller, sadakat programlarının asıl uygulayıcıları arasındadır. Otelcilik alanında çok kullanılmasına karşın, sadakat programları üzerinde sınırlı sayıda araştırmaya (Oyman,2002; Yeniçeri ve Erten, 2008; Yenidoğan, 2009; Artuğer, 2011; Özer, 2015; Deniz, 2016; Uncles, Dowling ve Hammond,2003; Lewis,2004;Gjivoje,2008; Xie ve Chen,2013; Laskarin,2013; Selvi ve Ercan,2006; Kerim ve Karademir,2019; Dekay, Toh ve Raven,2009; Chen ve Xie, 2014) rastlanmaktadır. Bu araştırmalarda çoğu zaman, sadakat programlarının müşteri bağlılığ üzerine etkisi ele alınmış, ancak otel yöneticileri gözünden bir değerlendirmenin olduğu bir çalışmaya rastlanmamıştır. $\mathrm{Bu}$ eksiklik, çalışmanın çıkış noktalarından birisini oluşturmaktadır. Sadakat programlarının uluslararası zincir oteller tarafından daha çok uygulanıyor olması nedeniyle, çalışmada bu otellerin yöneticilerinin perspektifinden sadakat programlarının başarı faktörleri, maliyet kalemleri ve uygulama aşamasında karşılaşılan sorunlar ortaya konmaya çalışılmıştır.

Uluslararası otel zincirlerinin yöneticileri gözüyle sadakat programlarını değerlendirmenin pratik gerekçeleri de bulunmaktadır. Her şeyden önce bu programları özellikle uluslararası zincir oteller uygulamaktadır. Ulusal zincir otellerde sadakat programları uygulamasının, ya olmadığı ya da çok sınırlı kaldığı gözlenmektedir. Uygulama süreçlerinin, beklentilerin ve başarı faktörlerinin uluslararası zincir otellerde görevli yöneticiler gözüyle tespit edilmesinin, ulusal zincir oteller için iyi bir kıyaslama örneği teşkil edebileceği düşünülmektedir.Diğer taraftan işletmelerde sadakat programları uygulamasında yaşanan sorunların irdelenmesi ve çözüm önerilerinin ortaya konması, otelcilik alanında müşteri yönlü bakış açısının yerleşmesinde etkili olabilir ve ulusal zincir otellerin uluslararası zincir otellere karşırekabet üstünlüğü sağlamasının temellerini oluşturabilir. 


\section{Kavramsal Çerçeve ve Literatür}

Sadakat kavramı, bir nesneye veya kişiye karşı duyulan samimi, dürüst duygular ve içten bağlanma durumu olarak tanımlanmaktadır (Oyman, 2002). Müşteri sadakati ise tüketicinin rekabet ortamında diğer alternatifleri göz ardı ederek işletmeyi veya işletmenin sunduğu ürünü tercih etmesi ve bu kararı sürdürme isteği olarak ifade edilmektedir (Baytekin, 2005: 49). Müşterilerde işletmeye yönelik olan sadakat, işletmenin sunduğu tüm ürünleri satın almaya teşvik eder. Müşterilerin ürüne yönelik geliştirdikleri sadakat duygusu ise o ürünü sürekli olarak satın alma davranışı göstereceği bir süreci ifade etmektedir (Yürük ve Kayapınar, 2016: 102).

Firmaların müşteri bağlılı̆̆ sağlamada kullandığı en önemli satış geliştirme araçlarından biri müşteri sadakat programlarıdır. $\mathrm{Bu}$ programların temelinde geleneksel pazarlama yöntemindeki satış geliştirme çabalarından farklı olarak müşterinin işletmeyle ya da ürünle olan ilişkisini devamlı kılma niyeti bulunmaktadır (Reinartz, 2006: 361).

Müşteri sadakat programları, bireylerin işletmeye ya da işletmenin sahip olduğu markalara bağlılığını sağlamak amacı ile uygulanan programlardır. Bu programlar sayesinde müşteriler çok sayıda seçenek içerisinde bağlı oldukları işletmeyi tercih etmektedirler. $\mathrm{Bu}$ tercih sonucunda işletmeler, müşterilerini kimi zaman maddi değer taşıyan avantajlarla, kimi zamansa ayrıcalıklı hissetmelerini sağlayacak uygulamalarla ödüllendirmektedir (Deniz,2016: $55)$.

Sadakat programları müşteriler için bağlılık hususunda önemli bir rol oynamakla beraber, ağızdan ağza pazarlamaya olanak sunan, fiyat duyarlılığını ve rakip firmaların ürünlerini tercih etme eğilimini en aza indirgeyen bir araçtır (Uncles, Dowling ve Hamlond, 2003: 303). Diğer yandan firmalarla müşteriler arasındaki iletişimi güçlendiren, çapraz satış imkanı yaratan, bilgiye erişimde kolaylık sağlayan ve müşterilerin beklenti ve isteklerine yönelik hizmet sunumuna olanak tanıyan önemli bir pazarlama aracıdır (Daryanto, Ruyter ve Wetzels, 2010: $604)$.

Turizm sektöründe müşteri sadakat programları, ilk olarak 1980'lerde ortaya çıkmıştır (Storm, 1999: 63). Müşterinin yalnızca satın alan birey olarak değil işletmenin var olmasında büyük önem taşıdığının farkına varılması ile işletmeler, yeni müşteriler kazanmak yerine mevcut müşterileri ellerinde tutmaya odaklanmışlardır (Aydın,2014: 42). Bu doğrultuda uygulanan sadakat programları, satın alma sonrası müşteriyi ödüllendirerek bağlılık duymasını sağlamakta ve tekrar satın alma davranışına zemin hazırlamaktadır (Lewis, 2004: 281). 
Otelcilik sektöründe sadakat programı,1983 yılında Holiday Inn tarafından uygulanmaya başlanmıştır. $\mathrm{Bu}$ program, konaklama ve otelin diğer alanlarında yapılan dolar başına harcamalara puan kazandıran ilk programdır (Laskarin, 2013: 112).Ardından Marriott Otel'de bu uygulamayı takip etmiştir. Günümüzdebirçok otel zinciri sadakat programı uygulamaya devam etmektedir. Hyatt otellerinin uyguladığı 'World of Hyatt', Wyndham otellerinin uyguladığg1 'Wyndham Rewards', Accor grubunun 'Accor Live Limitless', Radison zincirinin 'Radisson Rewards', Hilton Worlwide zincirinin 'Hhonors'. Starwood ve Marriot otel zincirlerinin 'Bonvoy', ve HolidayInn, ve Crowne Plaza gibi bir çok oteli bünyesinde bulunduran InterContinental Hotel grubunun uyguladığı 'IHG Rewards Club' otel zincirlerinde uygulanan sadakat programlarına örnek gösterilebilir.

Müşteri sadakat programları ile müşteri sadakati arasındaki ilişkiyi odaklanılan bir araştırmada; firmaya olan güvenin ilişkiyi sürdürmeyi olumlu yönde etkilediği $(\beta: 2,35)$ veilişkiyi sürdürme isteğinin de sadakati etkilediği $(\beta: 1,56)$ belirlenmiştir (Yeniçeri ve Erten, 2008). İstanbul'da faaliyet gösteren beş yıldızlı otel işletmelerinin sadakat programlarının incelendiği bir araştırmada (Özer, 2015); 81 otelden yaklaşık \%43’ü, sadakat programını bir pazarlama aracı olarak kullandığı ortaya çıkmıştır. Ayrıca sadakat programlarının maddi faydalarla ilgili en çok vurgulanan özelliği, \%84,6 oranıyla hediyeler (çekler, hediye kartları, ücretsiz tatiller, ücretsiz internet, ücretsiz uçak biletleri vb) olduğu belirlenmiştir. Maddi olmayan faydalar ile ilgili sadakat programlarının web sitelerinde en çok vurgulanan özelliği ise $\% 76,9$ oranıyla prestij, ayrıcalıklı hizmetler ve kolaylıklar olduğu ortaya konmuştur.

Otel işletmelerinde kullanılan sadakat programı kartlarının müşteri memnuniyetine ve bağlılığına etkisini belirlemeye yönelik yapılan bir araştırmada (Karademir,2019); katılımcılara yöneltilen "tercih ettiğim otellerde sadakat kart kullanılması otele olan bağlılığımı arttırır” görüşüne \%52,3'lük bir kısım "kesinlikle katılıyorum” cevabını vermiştir. Bu bulgudan yola çıkarak, otel işletmelerinde sadakat program kartlarının kullanılmasının bağlayıcılık konusunda büyük bir role sahip olduğu belirlenmiştir.

Xie ve Chen (2014) araştırmalarında; otel sadakat programlarının algılanan değerlerini incelemeyi, algılanan program değeri ile devamlı sadakat arasındaki ilişkiyi tanımlamayı ve algılanan program değerinin müşterilerin devamlı sadakatini belirlemedeki etkisini incelemeyi amaçlamışlardır. Veriler, çevrimiçi anket kullanarak toplanmıştır. Ankete katılanların en büyük kısmı (\% 28,97), sadık oldukları özel bir otel markasının bulunmadığını söylemiştir. ABD otel pazarında yaygın olarak kullanılan programların birbirine benzer özelliklere sahip olduğunu (r:0,310) ve devamlı müşteri sadakatini etkili bir şekilde artırabilmek için otellerin en uygun faydayı sağlayacak programlar geliştirmesi gerektiğini vurgulamışlardır. 
Nan Hua, Wei Wei, Agnes L. DeFranco ve Dan Wang (2018) araştırmalarında; sadakat programlarının otellerin operasyonel ve finansal durumları üzerindeki etkisini belirlemeyi amaçlamışlardır. Araştırmaları sonucunda sadakat programı harcamalarının satılabilir odabaşına gelir (RevPAR) $\left(\mathrm{r}^{2}: 0,658\right)$, ortalama günlük ücret (ADR) $\left(\mathrm{r}^{2}: 0,671\right)$ ve doluluk $\left(r^{2}: 0,168\right)$ ile ilgili üç operasyonel performans göstergesi ve brüt işletme karının finansal performans göstergesi üzerinde olumlu bir etkisi $\left(\mathrm{r}^{2}: 0,835\right)$ olduğunu bulgulamışlardır.

\section{Yöntem}

Araştırmanın amacı, otel sadakat programlarının yöneticiler perspektifinden değerlendirilmesidir. Bu amaç doğrultusunda şu sorulara cevap aranmaktadır:

1.Otelinizde uygulanmakta olan sadakat programlarından beklentileriniz nelerdir?

2.Sadakat programlarının müşteri bağl1lı̆̆ yaratmadaki rolü nedir?

3.Sadakat programlarının uygulanmasının maddi ve beşeri maliyetleri nedir?

4.Sadakat programlarının uygulanmasında sık yaşanan sorunlar nelerdir?

5.Sadakat programlarının uygulanmasında sık yaşanan sorunlara ne tür çözümler üretilmektedir?

6.Başarılı bir sadakat programı uygulamasının kilit başarı faktörleri nelerdir?

Araştırmada yarı yapılandırılmış görüşme tekniğinden yararlanılmış ve literatürden faydalanarak geliştirilen araştırma soruları, alanı pazarlama olan uzman bir öğretim üyesi tarafından amaca uygunluk bakımından kontrol edilmiştir. Yarı yapılandırılmış görüşme tekniğinde araştırmacı, sorularını önceden hazırlamaktadır. Araştırmacı, önceden hazırlanan sorulara karşın kişilerin yanıtlarını detaylandırması amacı ile ilave sorular da sorabilmektedir (Türnüklü, 2000: 547). Araştırma sorularının yanıtlarını verecek veriler, ikincil veriler ile görüşmeler yoluyla elde edilmiştir. Bu nedenle, özellikle görüşme yoluyla elde edilen nitel verilere, betimsel ve içerik analizi uygulanmıştır.

Nitel araştırmalarda geçerlilik, araştırmacının araştırdığı olguyu, olduğu biçimde ve olabildiğince yansız gözlemesi anlamına gelmektedir. Araştırmacının elde ettiği verileri ve bulguları teyit edebilmesi için bazı ek yöntemler bulunmaktadır. Bunlar; çeşitleme, katılımcı teyidi, meslektaş teyidi, vb. olabilmektedir (Yıldırım ve Şimşek, 2016: 269). Güvenilirlik ise, araştırmadan elde edilen bulguların ve yorumların tutarlı olması anlamına gelir. Diğer bir ifadeyle bulguların elde edildiği sürecin mümkün olduğunca şeffaf ve tekrar edilebilir olması gerekmektedir (Arastaman, Fidan ve Öztürk, 2018: 60). Bu doğrultuda içerik analizi ve 
kategorilendirme süreci, araştırmacı dışında farklı bir kişi tarafından tekrarlanmış ve benzer sonuçlara ulaşılmıştır. Benzerlik oranı, \%81'dir.

Araştırmanın evrenini, Türkiye'de faaliyet gösteren ve sadakat programı uygulayan yabancı otel zincirlerinin genel müdürleri ile satış ve/veya ön büro müdürleri oluşturmaktadır. Uluslararası zincir otellerin tercih edilmesinin sebebi, sadakat programlarının genellikle bu kategoride bulunan işletmeler tarafından kullanılıyor oluşudur. Çalışma evrenini ise, İstanbul ve Ankara'da faaliyet gösteren ve sadakat programı uygulayan uluslararası otel zincirlerinin genel müdürleri ile satış ve/veya ön büro müdürleri oluşturmaktadır. İstanbul ve Ankara'nın seçilmesinin birinci nedeni, sadakat programlarının çoğu zaman şehir otelleri tarafından uygulanıyor olmasıdır. İkinci neden ise uluslararası zincir otellerin çoğunun İstanbul ve Ankara' da faaliyet gösteriyor oluşudur. Bu iki şehirdeki yabancı zincir otellerinin web sayfaları üzerinde yapılan bir incelemede, iki şehirde 7 ayrı zincir otelin sadakat programı uyguladığg tespit edilmiştir. Dolayısıyla bu işletmeler amaçlı örnekleme yoluyla seçilmiştir.

Görüşmeler, 2020 yılının Şubat ayında gerçekleştirilmiştir. Veriler toplanmadan önce görüşme yapmayı kabul eden yöneticilerden randevu alınmıştır. Görüşmeler, katılımcıların müsait olduğu saatler doğrultusunda otellerde gerçekleştirilmiştir. Görüşme dönemi sonunda sadakat programı uygulayan yedi uluslararası zincir otelin 4'üne ait yöneticilerden randevu alınabilmiştir. Araştırmaya katılmayı kabul eden 15 yöneticiden 3’ü ses kaydı

alınmasını kabul etmiştir. Geri kalan 11 kişinin ise görüşme esnasında kullandıkları tüm ifadeler eksiksiz bir şekilde not alınmıştır. 15 otel genel müdürü ile yapılan görüşme sayısının nitel veri toplanan araştırmalarda en alt sınır olarak kabul edilmekle (Mason, 2010: 3) birlikte, verilerin birbirini tekrar etmeye başlaması nedeniyle görüşme süreci sonlandırılmıştır.

\section{Bulgular}

Uluslararası otel zincirlerinde yöneticilerin sadakat programlarından beklentileri, Tablo 1'de yer almaktadır. Yöneticilerin sadakat programlarından beklentilerinin \%40'a yakınını müşteri kaynaklı beklentiler oluşturmaktadır. $\mathrm{Bu}$ kategoride sadakat programlarından temel beklentinin müşterilerin daha iyi tanınması ve devamlılıklarının sağlanması olduğu ortaya çıkmaktadır.Yöneticilerin beklentilerinin üçte birini mali hususlar oluşturmaktadır. Bunlar içinde gelirleri arttırma ve aracılara bağlılı̆̆ azaltma dikkat çeken hususlardır. Bir diğer beklenti ise bu programların rekabet avantajı yaratmasıdır $(\% 27,8)$. Bu kategoride öne çıkan görüş ise tercih edilebilirliğin sağlanmasıdır. 
Tablo 1. Otel Sadakat Programlarından Beklentiler

\begin{tabular}{|l|c|c|c|c|}
\hline BEKLENTILER & $\mathrm{f}$ & $\%$ & $\mathrm{f}$ & $\%$ \\
\hline l.Müşsteri Kaynaklı Beklentiler & & & 14 & 38,9 \\
\hline Müşterilerin daha iyi tanınması & 5 & 35,7 & & \\
Müşteri devamlılığı edilen & 5 & 35,7 & & \\
Vaat hizmetlerin & 2 & 14,3 & & \\
gerçekleştirilmesi & 1 & 7,1 & & \\
Ulaşılabilirlik & 1 & 7,1 & & \\
Süreklilik & & & & \\
\hline 2.Mali Beklentiler & & & 12 & 33,3 \\
\hline Gelirleri arttırma & 7 & 58,3 & & \\
Aracılara bağl1lığı azaltma & 4 & 33,3 & & \\
Stratejik ortaklıklar kurma & 1 & 8,3 & & \\
\hline 3.Rekabet Avantajlı Beklentiler & & & 10 & 27,8 \\
\hline Tercih edilebilirlik & 6 & 60,0 & & \\
Reklam & 4 & 40,0 & & \\
\hline & & Toplam & 36 & 100 \\
\hline
\end{tabular}

Tablo 2'de uluslararası otel yöneticilerinin sadakat programlarının müşteri bağlılığı yaratmadaki rolüne ilişkin değerlendirmeleri bulunmaktadır. Sadakat programlarının müşteri bağlılı̆̆1 yaratmadaki en önemli rolü, müşteriye sağladığı kazanımlarla $(\% 60,7)$ ilgilidir. Bu programların müşteriye puan kazandırdığı, üyelik avantajları sağladığı ve müşteriye prestij sunduğu için bağl1lık yaratmada etkili olduğu düşünülmektedir. Diğer taraftan müşteri isteklerinin ilk elden öğrenilmesi ve standartlaştırılmış hizmet sunumuna katkı sağlaması da oteller açısından büyük önem taşımaktadır.

Tablo 2. Sadakat Programlarının Müşteri Bağlılığ1 Yaratmadaki Rolleri

\begin{tabular}{|l|c|c|c|c|}
\hline BA ĞLILIK YARATMA ROL ̈̈ & $\mathrm{f}$ & $\%$ & $\mathrm{f}$ & $\%$ \\
\hline 1.Müş̧teriye Dönük Kazanımlar & & & 17 & 60,7 \\
\hline Puan kazanma ve kazanılan puanları harcama & 6 & 35,3 & & \\
Ayrıcalıklı ve değerli hissetme & 5 & 29,4 & & \\
Üyelik avantajları & 6 & 35,3 & & \\
\hline 2.İşletmeye Dönük Kazanımlar & & & 11 & 39,3 \\
\hline
\end{tabular}




\begin{tabular}{|l|c|c|c|c|}
\hline Müşteri isteklerinin bilinmesi & 5 & 45,5 & & \\
Standartlaştırılmış hizmet & 5 & 45,5 & & \\
Müşteri görüşlerini dikkate almak & 1 & 9,0 & & \\
\hline & Toplam & 28 & 100 \\
\hline
\end{tabular}

Sadakat programlarının uygulanmasında maddi ve beşeri maliyetlere ilişkin değerlendirme sonuçları Tablo 3 'te yer almaktadır. Buna göre en önemli maliyet unsuru $(\% 44,8)$, personel ve tanıtım giderleridir. Bunlar içinde sadakat programı için özel olarak istihdam edilen personel gideri önemli bir kısmı oluşturmaktadır. Sisteme yapılan ödemeler $(\% 27,6)$ başka bir maliyet unsuru iken, müşteriye has yapılan hizmet sunumu da $(\% 27,5)$ üçüncü bir maliyet kalemidir.

Tablo 3.Sadakat Programlarının Maddi ve Beşeri Maliyetleri

\begin{tabular}{|c|c|c|c|c|}
\hline MALIYYET & $\mathrm{f}$ & $\%$ & $\mathrm{f}$ & $\%$ \\
\hline 1.Müşteri Giderleri & & & 8 & 27,6 \\
\hline Kişiye özel hizmet sunumunun maliyeti & 8 & 100,0 & & \\
\hline 2.Personel ve Tanıtım Giderleri & & & 13 & 44,8 \\
\hline İlave personel giderleri & 8 & 61,5 & & \\
\hline Sadakat programlarının reklam giderleri & 5 & 38,5 & & \\
\hline 3.Sisteme Yapılan Ödemeler & & & 8 & 27,6 \\
\hline Puan ödemesi & 8 & 100,0 & & \\
\hline \multicolumn{3}{|c|}{ Toplam } & 29 & 100 \\
\hline
\end{tabular}

Uluslararası otel zincirlerinin yöneticilerine göre, sadakat programlarının uygulanmasında sık yaşanan sorunlar, Tablo 4'de yer almaktadır. En sık rastlanan sorunların başında (\%50), sisteme ilişkin sorunlar gelmektedir. Puanların yüklenememesi en çok karşılaşılan sistemsel sorundur. Ayrıca bir kişinin birden fazla üyeliğinin olması ve üyeliğin yarattığı avantajlar da sistemsel sorunlar olarak değerlendirilmiştir.

Müşteri kaynaklı sorunlar (\%27,3), sık karşılaşılan ikinci sorun kategorisidir. Programın müşteri tarafindan anlaşılmaması veya müşterinin üye olduğu sadakat programının sağladığ 1 avantajlardan daha fazlasını talep etmesi, karşılaşılan müşteri kaynaklı sorunlar arasındadır. İşletme kaynaklı sorunlar, sadakat programlarının uygulanmasındaki $(\% 22,7)$ başka bir problem unsurudur. Bu kategoride personel kaynaklı sorunlar dikkat çekmektedir. 
Tablo 4.Sadakat Programı Uygulamalarında S1k Yaşanan Sorunlar

\begin{tabular}{|l|c|c|c|c|}
\hline SIK YAŞANAN SORUNLAR & $\mathrm{f}$ & $\%$ & $\mathrm{f}$ & $\%$ \\
\hline 1.Sistem Kaynaklı Sorunlar & & & 11 & 50,0 \\
\hline Aynı kişinin birden fazla üyeliğe sahip olması & 3 & 27,3 & & \\
Puanların yüklenmemesi & 5 & 45,4 & & \\
Üyelik avantajları & 3 & 27,3 & & \\
\hline 2.IŞsletme Kaynaklı Sorunlar & & & 5 & 22,7 \\
\hline Personel kaynaklı sorunlar & 4 & 80,0 & & \\
İşletmenin fiziksel yapısı sebebi ile & 1 & 20,0 & & \\
verilemeyen hizmetler & & & & \\
\hline 3.Müşteri Kaynaklı Sorunlar & & & 6 & 27,3 \\
\hline Programın anlaşılmaması & 3 & 50,0 & & \\
Müşterinin bir üst üyelik avantajını istemesi & 3 & 50,0 & & \\
\hline \multicolumn{2}{|c|}{ Toplam } & 22 & 100 \\
\hline
\end{tabular}

Sadakat programları uygulanırken yaşanan sorunlara karşı üretilen çözümler, Tablo 5 'te yer almaktadır. Yöneticiler karşılaşılan sorunları, en çok işletme düzeyinde çözmeye odaklanmaktadırlar $(\% 72)$. Bu çözümler arasında personel eğitimi $(\% 38,8)$ en sık kullanılan çözüm yoludur. Ayrıca geri bildirim değerlendirmesi, avantajların standartlaştırılması gibi çözümler getirilmeye çalışılmaktadır. Otel yöneticileri, karşılaştıkları sorunları sistem düzeyinde de çözmeye çaba harcamaktadırlar (\%28). Bu konuda teknik destek $(\% 71,4)$, en sık başvurulan sistemsel çözümler arasındadır.

Tablo 5. Sadakat Programı Uygulamalarında Yaşanan Sorunlara Üretilen Çözümler

\begin{tabular}{|l|c|c|c|c|}
\hline ÇÖZÜMLER & $\mathrm{f}$ & $\%$ & $\mathrm{f}$ & $\%$ \\
\hline 1.İŞletme Düzeyinde Çözümler & & & 18 & 72,0 \\
\hline Personel eğitimi & 7 & 38,8 & & \\
İdari toplantılar & 2 & 11,1 & & \\
Geri bildirim değerlendirmesi & 5 & 27,8 & & \\
Avantajların standartlaştırılması ve çeşitlendirilmesi & 3 & 16,7 & & \\
Sunulamayan hizmet yerine ikame hizmet sunma & 1 & 5,6 & & \\
\hline 2.Sistem Düzeyinde Çözümler & & & 7 & 28,0 \\
\hline Program içeriğinin geliştirilmesi & 2 & 28,6 & & \\
Teknik destek & 5 & 71,4 & & \\
\hline
\end{tabular}




\begin{tabular}{|r|c|c|}
\hline Toplam & 25 & 100 \\
\hline
\end{tabular}

Yöneticilerin sadakat programı uygulamalarının kilit başarı faktörleri olarak gördükleri hususlar, Tablo 6'da yer almaktadır.Sadakat programları uygulamasında kilit başarı faktörlerinin hemen hemen yarısı, işletme ile ilgili hususlardan $(\% 51,9)$ oluşurken, diğer yarısı da sisteme ilişkin hususlardan $(\% 48,1)$ meydana gelmektedir. İşletme ile ilgili hususlar arasında iletişim, en çok tekrar eden husustur. Sisteme ilişkin başarı faktörleri arasında ise erişebilirlik ve alt yapı dikkat çekmektedir.

Tablo 6. Sadakat Programı Uygulamalarının Kilit Başarı Faktörleri

\begin{tabular}{|l|c|c|c|c|}
\hline KİLİT BAŞARI FAKTÖRLERİ & f & \% & f & \% \\
\hline İşletme Faktörü & & & 14 & 51,9 \\
\hline Personel & 4 & 28,6 & & \\
İletişim & 6 & 42,8 & & \\
Misafirlerin bilgi ve tercihlerinin doğru analizi & 4 & 28,6 & & \\
\hline Sistem Faktörü & & & 13 & 48,1 \\
\hline Erişilebilirlik & 3 & 23,1 & & \\
Avantajların standartlaştırılması & 2 & 15,4 & & \\
Altyap1 & 3 & 23,1 & & \\
Avantajların çeşitlendirilmesi & 2 & 15,4 & & \\
Teknik destek & 2 & 15,4 & & \\
Lokasyon genişliği & 1 & 7,6 & & \\
\hline \multicolumn{3}{|c|}{ Toplam } & 27 & 100 \\
\hline
\end{tabular}

\section{Sonuç ve Öneriler}

Uluslararası otel zincirlerinde yöneticilerin sadakat programlarından temel beklentilerinin; müşterileri tanıma, işletmeye devamlılık sağlama ve bu doğrultuda gelirleri arttırma olduğu tespit edilmiştir. Sadakat programlarının; müşterileri tanıma, müşteri devamlılığı sağlama ve gelir arttırma üzerine etkisine 3 numaralı katılımcının verdiği cevap, güzel bir örnektir.

...Sadakat programlarının en önemli noktalarından biri otele gelen misafirin tanınması. Çünkü bu programlar detaylı veriler paylaşıyor ve aile gibi oluyorsunuz. İşletmelerin bu noktada beklentisi sadık müşteriler kazanma. Çünkü sadık müşteri kazanılırsa, müşteri rezervasyonlarını acente yerine otelin kendi 
sitesinden yapmayı tercih edecek ve aradan acente çekilecek. Bu noktada oda gelirleri konusunda da otele avantaj sağlayacak...

Sadakat programlarının müşteri bağlılığındaki rolü incelendiğinde, en büyük bağlılık unsurunun puan kazanma-harcama ve üyelik avantajları olduğu görülmüştür. 5 numaralı katılımcının cevabı, konuyu iyi özetlemektedir:

...Misafirlerde bağlılı̆̆ yaratan şartlardır. Puan kazanmak asıl sadakat sağlayıcıdır. Puanları alış-verişs sitelerinde bile kullanabilen misafir daha fazla puan kazanmaya yöneliyor ve bu da devamlı konaklamaya sebebiyet veriyor. Aynı zamanda sunulan farkl faydalar, örneğin; hediye ve ikramlar gibi, misafire özel hissettiriyor...

Sadakat programları uygulamasında maddi ve beşeri maliyetler incelendiğinde, yöneticilerin maliyet olarak düşündüğü kalem, personel ve tanıtım giderleridir. Maliyet kalemleri ile ilgili 6 numaralı katılımcı, şunları söylemiştir:

...Pazarlama çabaları büyük bir masraf kalemi. Özel salonlarda görevlendirmek üzere personel istihdami, program merkezinde çalışan personel gibi birçok istihdam da personel giderini arttırtyor...

Sadakat programı uygulamalarında karşılaşılan sorunların başında, sistem kaynaklı sorunlar gelmektedir. Sistem kaynaklı sorunlardan puanların yüklenmemesi, yöneticilerin üzerinde durduğu önemli bir konudur. Bu durumla ilgili 4 numaralı katılımcının beyanı şöyledir:

...Online rezervasyon olduğu sürece sistemler puanları otomatik olarak yüklüyor. Bu sürecin iyi işlemesi gerekiyor. Aksadığında puanlar yüklenmeyebiliyor ve problem yaşaniyor...

Sadakat programları uygulanırken yaşanan sorunlara üretilen çözümler incelendiğinde, üretilen çözümlerin genellikle işletme düzeyinde olduğu görülmektedir. En sık başvurulan çözüm yolu, personel eğitimidir. 10 numaralı katılımcının konu hakkındaki görüşleri şöyledir:

...Misafirlerin beklentilerinin iyi yönetilmesi gerekmektedir. Bu beklentilerin öncelikle net şekilde anlaşılması ve personelin bu beklentileri yönetebilmesi için gerekli ĕgitimden geçmesi gerekmektedir. Her olay bir Best Study olarak sürekli paylaşılmakta ve standart bir tavır geliştirilmesi için sürekli diyalog yüksek tutulmaktadir...

Uygulamalarda yaşanan sorunlar sistem kaynaklı olsa da sunulan çözümlerin işletme düzeyinde kaldığı da tespit edilmektedir. Bu noktada sistem kaynaklı sorunlar yaşansa dahi, 
işletmelerin bu sorunları personel ve sunduğu hizmet ile anlık olarak çözüme ulaştırdığı söylenebilir. Bununla ilgili 15 numaralı katılımcı, şöyle demiştir:

... Üyelik avantajları sunulurken otellerin fiziki yapılarından dolayı sorunlar çıkabiliyor. Bu servis farklılı̆̆ı yüzünden kullanılamayan imkânlar için içki veya yemek kuponları ve özel ikramlar gibi çözümler sunuluyor...

Sadakat programlarının kilit başarı faktörleri incelendiğinde, en önemli faktörün işletme faktörü olduğu görülmektedir. Yöneticiler, sadakat programı uygulamalarının başarılı bir şekilde işleyişini sürdürebilmesi için iletişim faktörünün büyük bir öneme sahip olduğunu belirtmektedirler. İletişim faktörünü 2 numaralı katılımcı, şöyle açıklamıştır.

...Doğru zamanda doğru kişilerle iletişim kurmak gerekiyor. Karşıdaki kişilere bu programın gerçekten avantajlı olduğunu iyi aktarmak gerekiyor. Misafirlerin geri dönüslerine cevap verirken doğru anı yakalamak ve onları düşündüğümüzü hissettirmek gerekiyor...

\subsection{Kuramsal Çıkarımlar}

Sadık müşteriler, işletmenin giderlerini arttırmak yerine gelirlerini arttırıcı bir etkiye sahiptir. Bu müşterileri kazanmak amacı ile uygulanan sadakat programları, yapılan yatırımlar sonucu uzun vadede işletmeye büyük bir fayda sağlamaktadır (Yenidoğan, 2009: 118). Yeniçeri ve Erten (2008: 244) araştırmalarında, müşterilerin işletme ile ilişki sürdürme isteği üzerinde, kişisel bilgilerin sadakat programları aracılığıyla avantaj olarak döneceğine duyulan güvenin ( $\beta$ : 0,235) önemli ölçüde etkisi olduğunu bulgulamışlardır. Bu bulguya paralel şekilde sadakat programlarının müşterileri tanımak ve devamlılık sağlamak açısından büyük önem arz ettiği yeniden teyit edilmektedir. Böylece oteller, gelen müşterileri tanıyarak, ihtiyaç ve beklentilerini bilerek ve her konaklamalarında onlara kişisel hizmet sunarak müşteri memnuniyetini ve güvenini kazanmayı sağlayabilmektedirler. Dolayısıyla daha sık satın alma ve gelirleri artırmanın da bir yolunu teşkil edebilmektedir.

Müşterilerin bir ürünü tekrardan satın alma isteği iki duruma bağlıdır. Bunlardan birincisi, müşterilerin satın alma sırasında elde ettiği avantajlar ve satış geliştirme destekleri gibi faydalardır. İkincisi ise belli bir ürüne yönelik geliştirdiği duygusal yakınlıktır (Çatı ve Koçoğlu, 2008: 169). İşletmeye gelen üye müşteriler, her konaklamalarında puan kazanıp, kazandıkları bu puanları yine aynı zincirin otelleri arasında harcama olanağı bulduğu ve konaklamaları esnasında bir takım üyelik avantajları (ücretsiz kahvaltı, odalara gönderilen ikramlar vb.) elde ettikleri için bir sonraki seyahatlerinde yine aynı zinciri tercih etmekte ve puan kazanımını sürdürmek istemektedirler. Satın alma sürecinde kazanılan faydalar 
sonucunda müşteride işletmeye bağglılık durumu oluşmaktadır. Bu bulgunun, Deniz'in (2016: 76) çalışması ile paralellik gösterdiği söylenebilir. Söz konusu çalışmada; otel işletmelerinde müşteri sadakatini en çok etkileyen dört değişken tespit edilmiştir. Bunlar; güven $(\% 22,7)$, önemsenmek (\%50), vazgeçilmezlik $(\% 6,8)$ ve ödüllendirmedir $(\% 20,5)$. Ayrıca otel işletmeleri müşterilerinde sadakat yaratabilmek için dört yöntem kullanmaktadır. Bunlar; ikram $(\% 15,9)$, indirim $(\% 13,6)$, hediye $(20,5)$ ve kişiselleştirilmiş hizmettir $(\% 50)$. Bu faydalar göz önünde bulundurulduğunda, sunulan hizmetlere yenileri eklenerek ve puanların kullanılabileceği yeni iş ortaklıkları kurularak sadakat duygusu güçlendirilebilir.

Berman (2006: 140) araştırmasında, sadakat programı işleyişinin personel ile paylaşılması gerektiğini vurgulamıştır. Böylelikle programın finansal öneminin tam olarak anlaşılacağını savunmuştur. Diğer yandan personelin, yeterli eğitim sayesinde programın genel hedeflerine ulaşmasına katkıda bulunacağı da belirtilmiştir. Dolayısıyla halihazırda uluslar arası otel zincirlerinde yöneticilerin benzer bakış açısıyla sadakat programlarının uygulamasında karşılaşılan sorunların üstesinden gelmeye çalıştıkları anlaşılmaktadır.

Berezan, Yoo ve Christodoulidou (2015: 110), program üyeleri tarafindan kullanılan iletişim kanallarının, iletişim tarzı ve bilgi kalitesi algılarına etki ettiğini, dolayısıyla iletişimin programa duyulan sadakati etkilediğini belirtmişlerdir. Bu noktada her uygulamada olduğu gibi, uygulamanın kendisinin yanı sıra, onu aktaran ve uygulayan personel de büyük önem kazanmaktadır. Müşterinin ilk olarak diyalog kurduğu kişi çalışanlardır. İşletmeler, programları personeline iyi bir şekilde aktarmalıdır. Böylelikle personel, program ve işleyişini iyi bir şekilde kavramalı ve hedef kitleye programı eksiksiz bir şekilde aktarabilmelidir. Bunun yanı sıra müşteri beklentilerinin daha iyi anlaşılmasına paralel olarak hizmet sunumunun beklentilere hitap edecek şekilde gerçekleştirilmesi de gerekmektedir. Bu süreç, misafirlerin kendilerini değerli ve özel hissetmeleri ve ayrıca, sağlanan avantajlarla sadakat programına olan güvenlerinin artması için iyi bir zemin hazırlayabilir ve böylece sadakat programının amacına ulaşmasıyla sonuçlanabilir.

\subsection{Uygulamaya Dönük Çıkarımlar}

Araştırma, sadakat programı uygulama düşüncesi olan diğer işletmeler, özellikle ulusal zincir oteller için çeşitli bilgiler sunmaktadır. Programların getirileri, yaşanılan sorunlar, bu sorunlara üretilen çözümler ve maliyet kalemleri, programın ayrıntıları ve işleyişi ile ilgili yöneticilerin zihninde iyi bir temel oluşturabilir. Hangi sorunlara nasıl çözümler üretildiği ve kilit başarı faktörlerinin neler olduğu da, konuya ilgi duyan otel yöneticilerinin dikkate alabilecekleri hususlardır. Dolayısıyla otel yöneticilerine, devamlı müşteri sadakatini etkili bir şekilde 
sağlayabilecek, hem otele hem de müşteriye uygun bir dengede maksimum faydayı sağlayabilecek sadakat programlarının geliştirilip uygulanması önerilmektedir.

Sadakat programlarını uygulama aşamasında geri planda her zaman teknik bir ekip bulunmaktadır. Müşterilerin, programlarla ilgili sorunları olduğunda veya üyelik avantajları ile ilgili destek istediklerinde bir çağrı merkezi düzenli olarak hizmet vermektedir. Ayrıca üyelik avantajları kapsamında özel salon kullanımı ve odalara ücretsiz ikramda bulunma gibi birçok fayda sunulmaktadır. Bu operasyonun kilit noktasını ise personel oluşturmaktadır. Dolayısıyla tüm bunlar da gider kalemi olarak değerlendirilmektedir. Bununla birlikte daha fazla kişiye ulaşabilmek adına sponsorluk ve reklam gibi bir takım tutundurma faaliyetlerinin de gerçekleştirilmesi, maliyet arttırıcı uygulamalar olarak karşımıza çıkmaktadır. Müşteriyi işletmeye sadık hale getiren en önemli faktörün puan kazanma olduğu göz önünde bulundurulduğunda, bu durum üzerinde durulması gereken önemli bir sorunu teşkil etmektedir. Teknik ekip, sorunun nereden kaynaklandığını tespit etmek için çalışmalar gerçekleştirmeli ve sorun ile ilgili kalıcı çözümler üretmelidir.

\subsection{Akademik Öneriler}

Araştırmanın en önemli kısıdı, katılımcı sayısının sınırlılığıdır. Sonraki çalışmalarda katılımcı sayısı arttırılabilir. Verilerin sadece yöneticilerin söyledikleriyle sınırlı olması da başka bir kısıttır. Yönetici görüşleriyle elde edilen sonuçların güçlendirilmesi ve/veya teyit edilmesi, ancak sadakat programı ayrıntılarının, muhasebe kayıtlarının ve müşteri veri tabanındaki bilgilerin araştırmacılarla paylaşılması ile gerçekleştirilebilir. Bu konuda işbirliği yapan tek bir otel zinciri bile olsa, örnek olay çalışmaları şeklinde irdelemelerin yapılması, alana önemli katkı sağlayabilir. 


\section{KAYNAKLAR}

Arastaman, G., Öztürk Fidan, İ. ve Fidan, T.(2018). Nitel Araştırmada Geçerlik ve Güvenirlik: Kuramsal Bir İnceleme. Yüzüncü Yll Üniversitesi Eğitim Fakültesi Dergisi, 15(1), 37-75.

Artuğer, Savaş. 'Sık Uçan Yolcu Programlarının Müşteri Bağlılı̆̆ı Üzerine Etkisi'’.Doktora Tezi, Adnan Menderes Üniversitesi, 2011.

Atay, Yaprak. "Sadakat Programlarında Verilen Ödüllerin Değer Algısı ve Program Sadakati Üzerine Etkileri” Yüksek Lisans Tezi, Hacettepe Üniversitesi,2020.

Ay, Esra.' Müşteri İlişkileri Yönetimi Aracı Olarak Sadakat Kartlarının Müşteri Memnuniyeti ve Bağlılığına Etkileri Üzerine Bir Araştırma (Perakende Sektörü)' 'Yüksek Lisans Tezi,Selçuk Üniversitesi, 2014.

Aydın, Onur. ''Havayolu Müşteri Sadakat Programının Evrimi: Miles \& Smiles Örneği.'’Yüksek Lisans Tezi, Maltepe Üniversitesi, 2014.

Baytekin, Evrim Pelin (2005)', Toplam Kalite Yönetiminde Müşteri Memnuniyetinden Müşteri Sadakatine’, Yeni Düşünceler, 1(1),41.52

Berazan, O. Yoo, M. ve Christodoulidou, N (2015). 'The Impact of Communication Channelson Communication Style and Information Quality for Hotel Loyalty Programs', Journal of

Hospitality and Tourism Technology. 7(1),100-116.DOI: 10.1108/JHTT-08-2015-0031

Berman, B (2006). ' 'Developing an Effective Customer Loyalty Program'. CaliforniaManagement Review. 49(1) 123-148. DOI: $10.2307 / 41166374$

Çatı, K. ve Koçoğlu, M.C (2008). '’Müşteri Sadakati İle Müşteri Tatmini Arasındaki İlişkiyiBelirlemeye Yönelik Bir Araştırma',.Selçuk Üniversitesi Sosyal Bilimler Enstitüsü Dergisi, 19, 167-188.

Daryanto, A. Ruyter, K.D ve Wetzels, M.(2016). Service Firms and Customer Loyalty Programs: a Regulatory Fit Perspective of Reward Preferences in a Health Club Setting. J. of the Acad. Mark. Sci. 38, 604-616.

Dekay, F., Rex, T. Ve Raven, P.2009. 'Loyalty Programs: Airlines Outdo Hotels' .Corner Hospitality Quarterly 50(3) 371-382. DOI: 10.1177/1938965509338780

Demirel, Y (2007). 'Türk Bankacılık Sektöründe Müşteri İlişkileri Yönetimi'nin Müşteri Sadakati Üzerine Etkisi'’. Kocaeli Üniversitesi Sosyal Bilimler Enstitüsü Dergisi. 1(13), 56-81.

Deniz, Ezgi. 'Müşteri İlişkileri Yönetiminde Sadakat Programları ve Otel İşletmelerinde Uygulanması'’.Yüksek Lisans Tezi, İstanbul Üniversitesi, 2016.

Gjivoje, D (2008). 'Where Leads Modern Loyalty Programs On Tourism Market'’. ActaTuristica Nova. 2(1) 2549.

Hammond, K., Uncles, M., \&Dowling, G (2003). 'CCustomer Loyalty and Customer Loyalty Programs'. Journal of Consumer Marketing. 20(4), 294-316. DOI: 10.1108/07363760310483676

Karademir, S.,"Otel İşletmelerinde Kullanılan Sadakat Program Kartlarının Müşteri Memnuniyeti ve Bağlılığına Etkisine Yönelik Bir Araştırma", Yüksek Lisans Tezi, İstanbul Aydın Üniversitesi, 2019

Karademir, S. ve Kerim, G (2019). 'Sadakat Kartlarının Otel İşletmelerinde Müşteri Memnuniyeti ve Bağlılığına Etkisine Yönelik Bir Araştırma',,Sürdürülebilir Yönetim ve Kalkınma Sempozyumu bildiriler kitabı içinde( 1-14). Aydın: Aydın Üniversitesi.

Klophaus, R (2005). 'Frequent Flyer Programs For Europe an Low-Cost Airlines: Prospects, Risks And Implementation Guidelines', Journal of Air Transport Management. 11(5), 348353.DOI: 10.1016/j.jairtraman.2005.07.001

Laskarin, M (2013). 'Development Of Loyalty Programmes In The Hotel Industry'. Tourism and Hospitality Management. 19(1), 109-123.

Lewis, M (2004). '"TheInfluence of Loyalty Programs and Short-TermPromotions on Customer Retention'. Journal of Marketing Research. 41(3) 281-292.DOI: 10.1509/jmkr.41.3.281.35986

Mason, M (2010). 'Sample Size and Saturation in PhD Studies Using Qualitative Interviews''.Forum Qualitative Social Research.11(3), 1-19.

Nan Hua, Wei Wei, Agnes L. DeFranco, Dan Wang, (2018) "Do loyalty programs really matter for hotel operational and financial performance?", International Journal of Contemporary Hospitality Management, Vol. 30 Issue: 5, pp.2195-2213

Oyman, M (2002). 'Müşteri Sadakati Sağlamada Sadakat Programlarının Önemi', Kurgu Dergisi. 19, 169-185

Özer, S (2015).'’ İstanbul'da Faaliyet Gösteren Beş Yıldızlı Otel İşletmelerinin Müşteri Sadakat Programlarının İçerik Analizi'”. Ekonomi ve Yönetim Araştırmaları Dergisi. 4(1), 134-157.

Reinartz, W. J. (2006). Understanding Customer Loyalty Programs. In Retailing in the 21st Century (pp. 361379). Berlin, Heildelberg: Springer.

Selvi, M.S. ve Ercan F (2006). 'Otel İşletmelerinde Müşteri Sadakatinin Değerlendirilmesi: İstanbul'daki Beş Yıldızlı Otel İşletmelerinde Bir Uygulama', Sosyal Bilimler Dergisi. 9(5) 159-188

Storm, S (1999). "Air Transport Policies and Frequent Flyer Programmes in the EuropeanCommunity - a Scandinavian Perspective" .Unit of Tourism Research at Research Centre of Bornholm. 11-105. 
Türnüklü, A.(2000). Eğitimbilim Araştırmalarında Etkin Olarak Kullanılabilecek Nitel Bir Araştırma Tekniği: Görüşme. Kuram ve Uygulamada Eğitim Yönetimi. 24(24), 543-559.

Xie, L. ve Chen, C (2014). ' 'Hotel Loyalty Programs: How Valuable Is Valuable Enough?'’ International Journal of Contemporary Hospitality Management. 26(1),107 - 129.DOI: 10.1108/IJCHM-08-2012-0145

Yeniçeri, T. ve Erten, E (2008). ' 'Mağaza Sadakat Programlarının Algılanması, Güven, İlişkiyi Sürdürme İsteği ve Mağaza Sadakati Arasındaki İlişkilerin Yapısal Eşitlik Modeli İle İncelenmesi' . Doğuş Üniversitesi Dergisi. 9(2), 232-247.

Yenidoğan, T (2009). 'Müşteri Sadâkat Programları: Pazarlama Yazınında Bakış Açıları ve Genel Bağlam”. Balıkesir Üniversitesi Sosyal Bilimler Enstitüsü Dergisi. 12(21), 116-138.

Yıldırım, Özlem“'Termal Turizm İşletmelerinde Müşteri Sadakati ve Bir Araştırma'. Yüksek Lisans Tezi, Balıkesir Üniversitesi,2005.

Yıldırım, A. ve Şimşek, H.(2016) Sosyal Bilimlerde Nitel Araştırma Yöntemleri. Seçkin Yayıncılı,, Ankara.

Yürük, P. ve Kayapınar, Ö. (2016). "İlişki Pazarlaması Bileşenleri ile İmaj ve Müşteri Sadakati Arasındaki İlişkilerin İncelenmesine Yönelik Bir Uygulama", Balkan ve Yakın Doğu Sosyal Bilimler Dergisi, 02(02), 100. 